\title{
Presence of Adhesive Vesicles in the Mycoherbicide Alternaria helianthi
}

\author{
Hamed K. Abbas ${ }^{1} \&$ Rex N. Paul ${ }^{2}$ \\ ${ }^{1}$ United States Department of Agriculture-Agricultural Research Service, Biological Control of Pests Research \\ Unit, Stoneville, MS 38776, United States \\ ${ }^{2}$ United States Department of Agriculture-Agricultural Research Service, Crop Production System Research \\ Unit (formerly: SWSRU), Stoneville, MS 38776, United States \\ Correspondence: Hamed K. Abbas, USDA-ARS, Biological Control of Pests Research Unit, Stoneville, MS \\ 38776, United States. Tel: 662-686-5313. E-mail: hamed.abbas@ars.usda.gov
}

Received: February 5, 2015 Accepted: March 23, 2015 Online Published: March 26, 2015

doi:10.5539/jps.v4n2p21 URL: http://dx.doi.org/10.5539/jps.v4n2p21

\begin{abstract}
Alternaria helianthi conidia have been shown to cause disease on common cocklebur. Alternaria helianthi conidia grown at $18{ }^{\circ} \mathrm{C}$ are more virulent than those grown at $28{ }^{\circ} \mathrm{C}$, and adhere to the leaves of the treated plants and causes necrotic lesions, stunting and mortality in common cocklebur at the 6- to 12-leaf stage. Using confocal laser scanning microscopy (CLSM) the virulent conidia produced multiple branched germ tubes. The distribution of the adhesive material on the conidial surface was varied, being evenly distributed on some conidia while appearing as globules on others. Examination by transmission electron microscopy (TEM) showed that virulent conidia had dense ribosomes and abundant endoplasmic reticulua indicating actively synthesizing cytoplasm. Adhesive vesicles, which appear to be the means of export of the adhesive from the cytoplasm, were often arranged along external cell walls. An osmophilic material, possibly the adhesive substance itself, was seen between the cell membrane and the cell wall. This substance may play an important role in the virulence of $A$. helianthi to common cocklebur and survival of this pathogen.
\end{abstract}

Keywords: ultrastructure, adhesive material, electron microscopy, fungi, conidia, biological control, temperature

\section{Introduction}

Common cocklebur (Xanthium strumarium L.) is an important weed in many areas and on many crops (Abbas et al., 1996; Abbas et al., 1999; Bloomberg et al., 1982; Buchanan \& Bruns, 1971; Holm et al., 1977; Soltani et al., 2010; Weaver \& Lechowicz, 1983). Alternaria helianthi (Hansf.) Tubaki and Nishihara] is a pathogen of cocklebur and other plants (Abbas et al., 1995; Morris et al., 1983; Quimby, 1989). Alternaria helianthi is an effective mycoherbicide for biological control of cocklebur (Abbas and Barrentine, 1995; Abbas and Egley, 1996; Abbas et al., 1996; Abbas et al., 2004; Sanyal et al., 2008; Quimby, 1989). We have previously reported that temperature is an important factor in the development of disease on common cocklebur caused by $A$. helianthi. Conidia of $A$. helianthi produced at $18{ }^{\circ} \mathrm{C}$ were more virulent than those grown at $28^{\circ} \mathrm{C}$.

There are many reports that many fungi such as Alternaria species, Uncinuliella australiana [(Ces.) Wils.], Colletotrichum graminicola [(McAlpine) R. Y. Zheng \& G. Q. Chen] produce adhesive vesicles involved in their survival and pathogenicity (Mims et al., 1995a; Mims et al., 1995b; Mims et al., 1997; Silva et al., 2014).

Electron microscopy has been an excellent tool in determining the mechanism of infection of hosts by fungal pathogens (Cleary et al., 2013; Garcia et al., 2012; Silva et al., 2014). Ascochyta anemones causes leaf spot of windflower in China. It has been reported that windflower is infected by one tube from the fungus penetrating the leaf cuticle (Dan et al., 2012). In infection of barley by Erysiphe gramimis, the fungus dissolves the cuticle for a point of entry (Kunoh et al., 1988; Nicholson \& Epstein, 1991). The fungus Zygophiala jamaicensis causes flyspec on fruits to secrete large amounts of mucilage creating a path for the fungal hyphae to penetrate the cuticle (Nasu \& Kunoh, 1986). Deising et al., 1992 described what is termed an adhesion pad in Uromyces providing information that serine esterase is essential to the adherence of the pad to the leaf surface. It has been reported that the fungus Colletotrichum graminicola releases adhesive materials which are responsible for adherence to hydrophobic surfaces (Mercure et al., 1994; 1995). More recently Silva et al., 2014 described adhesive materials that play a very important role in the virulence of the fungus Alternaria infectoria. 
In this research, we have attempted to determine by electron microscopy, confocal laser scanning microscopy (CLSM), scanning electron microscopy (SEM), and transmission electron microscopy (TEM), how the adhesive apparatus of $A$. helianthi conidia attaches to the host, common cocklebur and establishes infection, causing disease and death of the plant.

\section{Method}

\subsection{General}

\subsubsection{Conidia of Alternaria helianthi}

Culture and growth of $A$. helianthi at various temperatures as well as histochemical and ultrastructural studies were described in detail by Abbas et al., 1995. In order for the conidia of $A$. helianthi to be used for the adhesive materials research, we ran quality control evaluation of conidia for their virulence using the assays described in detail in (Abbas \& Barrentine, 1995; Abbas et al., 1995; Abbas et al., 2004). All the evaluations were measured visually by looking for damage symptoms on 3 replicates of 6 plants each in the greenhouse. Evaluations occurred after $10-14$ days post inoculation. Symptoms included necrotic lesions, growth inhibition, and mortality (Figure 1). Conidia were evaluated for germination using light and electron microscopy for number, length of germ tube and also using visual assessment (Figure 2). Figures 1 and 2 were generated from the same conidia used to study the adhesive materials (Figures 3 and 4). This was done to make sure the research for the adhesive materials would be conducted on virulent conidia.

\subsection{Adhesive Material Studies}

All sample protocols including preparation of samples, materials, steps for cutting and bedding of samples, and conditions of electron microscopy in this study were as described before in detail by Abbas et al., 1992; and Abbas et al., 1995. Briefly, all specimens were fixed in $4 \%$ glutaraldehyde $+0.5 \%$ caffeine for $3 \mathrm{hrs}$ at room temperature. After washing (1hr in buffer) some tissues were stained in block before embedding with mercuric bromphenol blue (MBB), a general protein stain (Abbas et al., 1995). Another set of tissues was set aside after initial fixation for sectioning and histochemistry. The rest of the samples were post-fixed in $1 \% \mathrm{OsO}_{4}$ for $2 \mathrm{hrs}$. All tissues were then washed in distilled $\mathrm{H}_{2} \mathrm{O}$, dehydrated in acetone and embedded in Spurr's resin. A set of samples from each of the following lists were semi-thin sectioned, attached to glass slides and stained in toluidine blue for general light microscope observation.

\subsection{Confocal Laser Scanning Microscopy}

Conidia cells were adhered to slides dipped in dimethyldichlorosilane solution ( $5 \%$ solution $[\mathrm{v} / \mathrm{v}]$ in methylene chloride). This makes the surface hydrophobic, emulating leaf wax (Mercure et al., 1994). Aqueous suspensions of conidia were placed on the dipped surface and allowed to sit for $0.5-1 \mathrm{hr}$. The slides containing the conidia were rinsed twice in $1 \mathrm{ml} 0.05 \mathrm{M}$ glycine in phosophate buffered saline (PBS) and then stained $0.5 \mathrm{hr}$ with FITC conjugated lectin Con A (Sigma-Aldrich) at a concentration of $200 \mu \mathrm{g}$ per $\mathrm{ml}$ of PBS solution (Mercure et al., 1995). A drop of $50 \%$ glycerin water was placed over the adhered, stained conidia and the samples were observed using a Zeiss LSM 410 confocal microscope.

\subsection{Transmission Electron Microscopy}

Specimens were fixed in $4 \%$ glutaraldehyde $+0.5 \%$ caffeine for $3 \mathrm{hrs}$ at room temperature. After washing $1 \mathrm{hr}$ in cacodylate buffer, the tissue was post fixed in $1 \% \mathrm{OsO}_{4}$ for $2 \mathrm{hrs}$. The material was washed $1 \mathrm{hr}$ in distilled water, dehydrated in a graded acetone series and embedded in Spurr's resin. Thin sections were stained with $1 \%$ uranyl acetate, post-stained in lead citrate, then observed and photographed using a Zeiss EM 10 transmission electron microscope.

\subsection{Scanning Electron Microscopy}

Conidia adhered to dimethyldichlorosilane coated (dipped) cover slips were fixed in osmium vapor overnight, allowed to air dry, then coated with $20 \mathrm{~nm}$ of $\mathrm{Au} / \mathrm{Pd}$. The specimens were observed and photographed in a JEOL JSM 840 scanning microscope.

\section{Results}

\subsection{General Description of Samples}

Conidia of $A$. helianthi produced at $18^{\circ} \mathrm{C}$ were virulent on common cocklebur plants. The treated plants exhibited damage symptoms of necrotic lesions on plant tissues (leaves and stems), growth inhibition, and mortality (Figure 1) to 6- to 12- leaf multiple seeded common cocklebur (MSC) and to 6- to 8- leaf normal common cocklebur (NCC) in greenhouse when plants were treated with 50,000 conidia /ml, after 10 to 14 days 
after treatment.
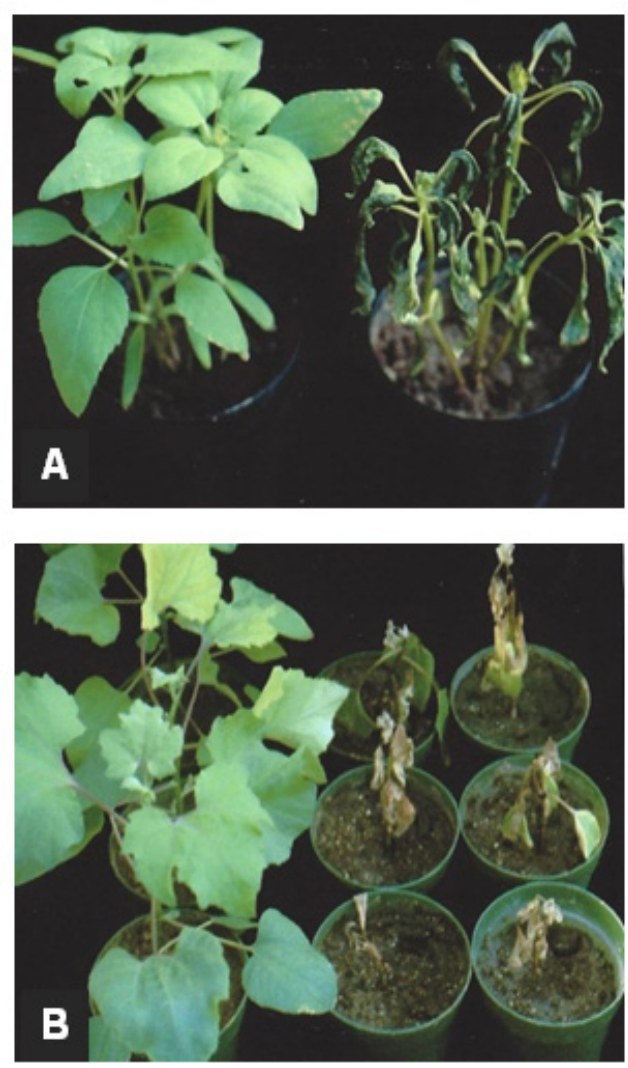

Figure 1. A. Multiple seeded common cocklebur (Abbas et al., 2004; Sanyal et al., 2008); and B. normal common cocklebur (Abbas and Barrentine, 1995; Abbas et al., 1996) plants treated with conidia produced at $18{ }^{\circ} \mathrm{C}, 14$ days after treatment with control on the left, respectively

The conidia of $A$. helianthi are multicellular. There appears to be some division of labor within the individual conidium in that the individual segments often stain very differently. Some segments, even in the $18{ }^{\circ} \mathrm{C}$ control tissue appear empty. The number of empty segments increases with exposure to $28{ }^{\circ} \mathrm{C}$ temperature with the greatest change(s) occurring at 48 - $72 \mathrm{hrs}$. At $72 \mathrm{hrs}$, there are almost no unaffected conidia. Most conidia at this temperature consist of predominantly empty shells with only a few filled. At $28^{\circ} \mathrm{C}$, conidial segments filled with cytoplasm are rare, but make up the most visible aspect of the samples since the predominant structures are the empty shells of atrophied conidia. Also, under both light and electron microscopy, conidia grown at $18{ }^{\circ} \mathrm{C}$ produced aggressive, branched, and long and multiple germ tubes (Figure 2). 

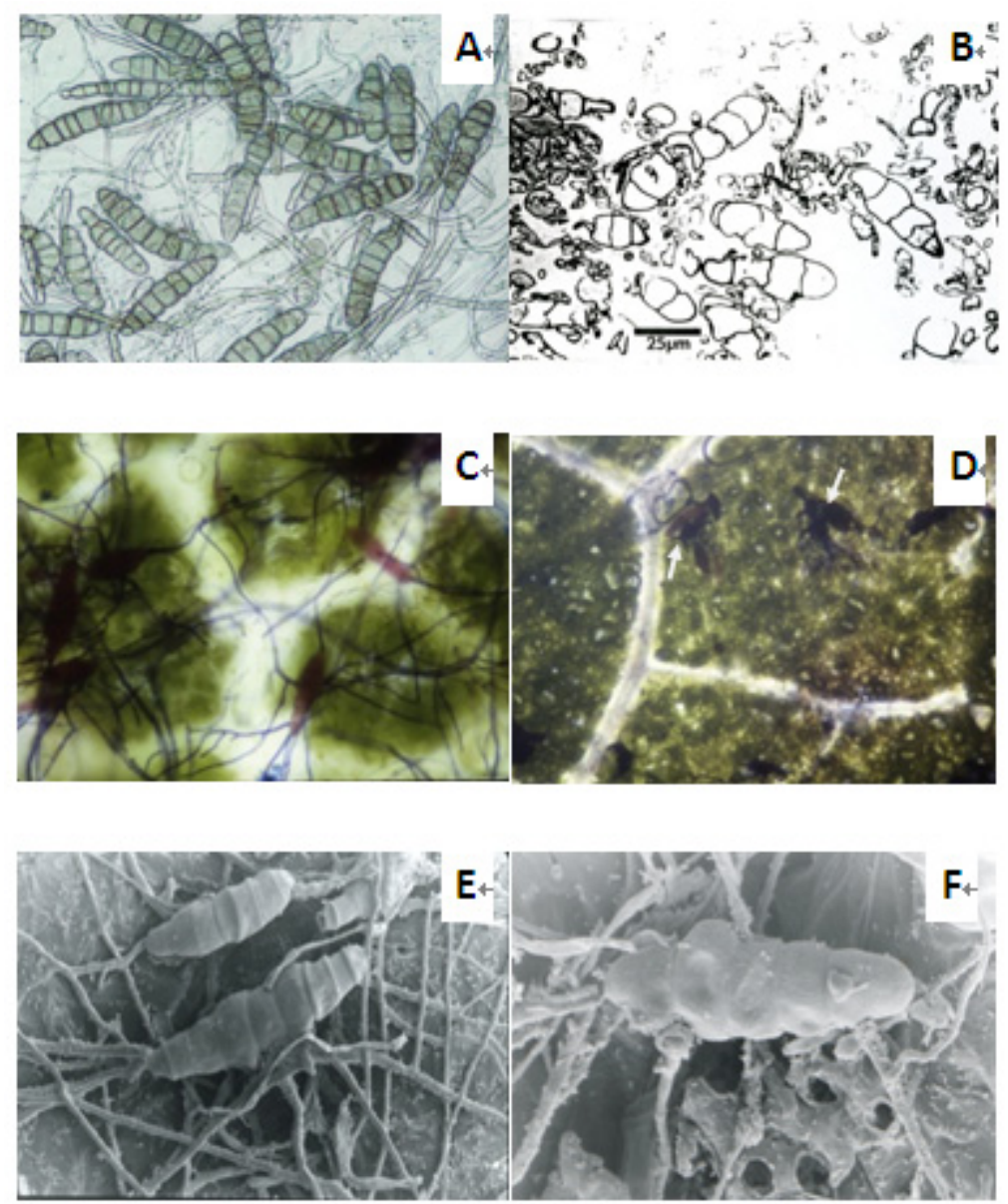

Figure 2. A. Conidia of $A$. helianthi grown at $18^{\circ} \mathrm{C}$. B. Conidia of $A$. helianthi grown at $28^{\circ} \mathrm{C}$. C. Germinating conidia on leaf surface of common cocklebur $\left(18^{\circ} \mathrm{C}\right)$. Note multiple germ tubes after $24 \mathrm{hrs}$ after application. D. Germinating conidia on leaf surface of common cocklebur $\left(28^{\circ} \mathrm{C}\right)$. Note a very few, weak, short multiple germ tubes after $24 \mathrm{hrs}$ after application in comparison with germinating conidia $\left(18^{\circ} \mathrm{C}\right)$ described previously in C. E $\&$ F. SEM of germinating conidia of $A$. helianthi grown at $18{ }^{\circ} \mathrm{C}$. Note multiple germ tubes with clear point of the emerging of the germ tube from the cell of each conidia in close up as shown in F. (A, B, C, \& D bars $=25$ $\mu \mathrm{m}$; and $\mathrm{E} \& \mathrm{~F}$ bars $=10 \mu \mathrm{m})$

Also, conidia produced at $18{ }^{\circ} \mathrm{C}$ under electron microscopy demonstrated the presence of adhesive materials (Figures 3 and 4). Conidia produced at $28^{\circ} \mathrm{C}$ were less virulent, produced weak, short, non-branched germ tubes, and lacked adhesive materials in comparison to the conidia produced at $18^{\circ} \mathrm{C}$.

\subsection{Adhesive Material Studies}

\subsubsection{Ultrastructural Effects}

The individual segments of control $\left(18{ }^{\circ} \mathrm{C}\right)$ conidia apparently vary in physiological state. Adjacent segments often have very different appearances related to inclusions present, cytoplasmic density and organelles visible. At higher magnification, one sees mitochondria $(\mathrm{Mt})$, nuclei $(\mathrm{N})$, microbodies $(\mathrm{Mb})$ and certain inclusions $(\mathrm{I})$. Very dense osmiophilic structures are present randomly spaced in the cytoplasm or lined up along the plasmalemma are apparently related to conidial adhesion, and possibly are carrying adhesive material to the plasmalemma to be exported to the conidial surface.

The conidia produced at $18{ }^{\circ} \mathrm{C}$ adhered to the dipped slides in larger numbers in comparison to the control conidia. The conidia grown at $28{ }^{\circ} \mathrm{C}$ did adhere, except rarely - most were rinsed off. This indicates a lack of ability of the heat-grown conidia to produce the adhesive material, stick to the surface, and be present for staining. This would affect only the confocal microscopy as described above, since it requires adhesion of the conidia for subsequent image processing. These results are summarized in detail in Figures 3 and 4. 

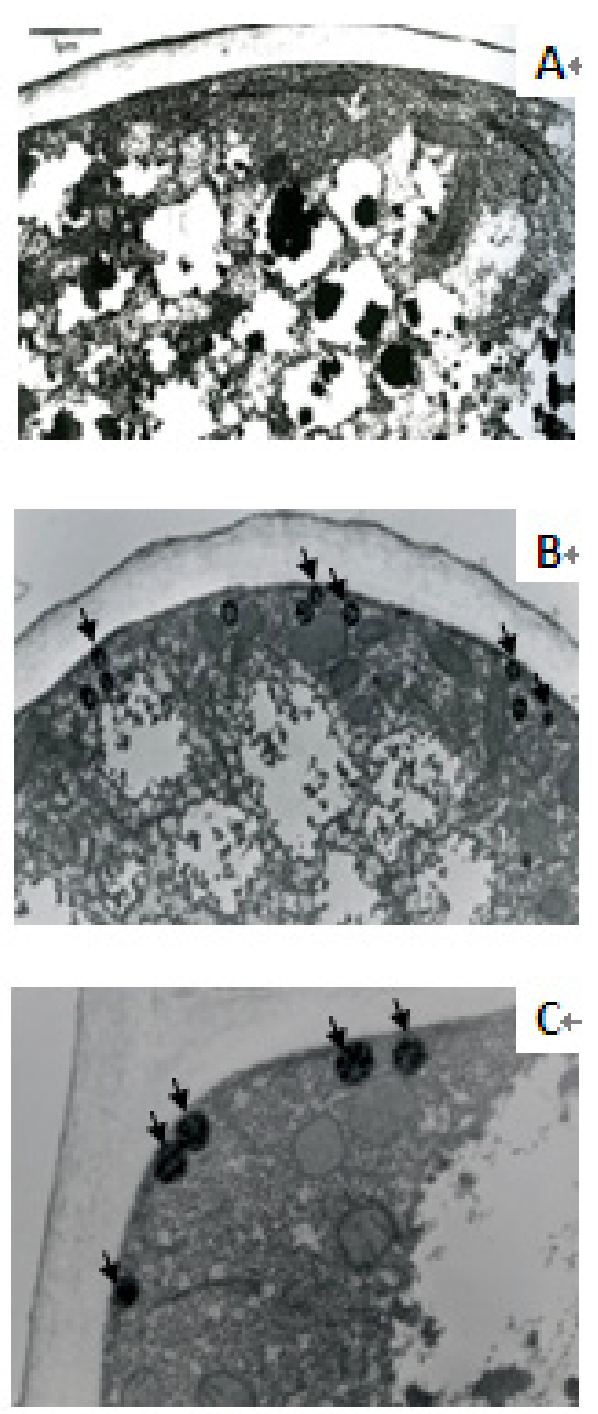

Figure 3. A. TEM of edge of conidium grown at $28^{\circ} \mathrm{C}$. Note the absence of adhesive vesicles when compared to $18{ }^{\circ} \mathrm{C}$ grown conidia. B. TEM of edge of conidium grown at $18^{\circ} \mathrm{C}$. Arrows denote adhesive vesicles which are lined close to the cell wall. And C. Close-up shot of B (All bars $=1 \mu \mathrm{m})$ 

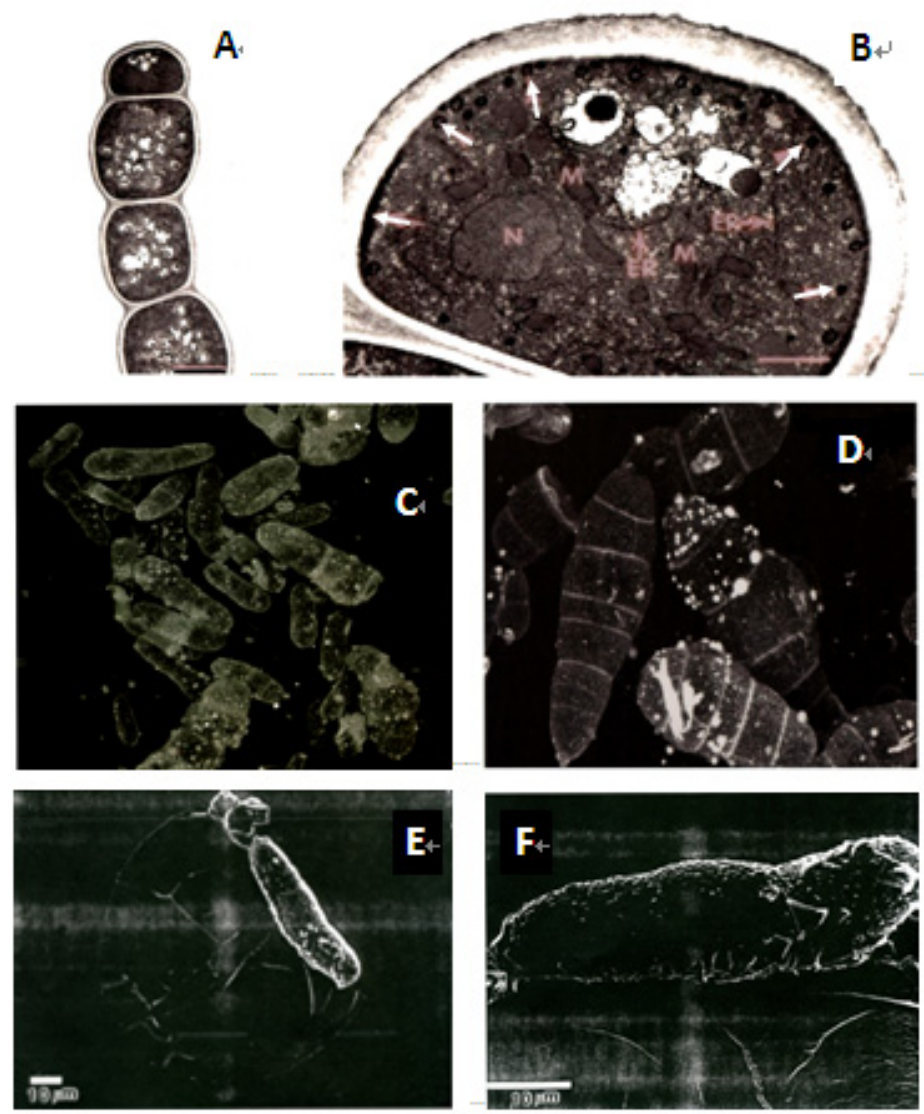

Figure 4. Transmission electron and confocal laser scanning micrographs of $A$. helianthi conidium grown at $18^{\circ} \mathrm{C}$. A. TEM of conidium shows 4 adjacent cells. B. Higher magnification micrograph of apical cell of conidium shown in Figure 4A. Small cytoplasmic inclusions (white arrows) are probably adhesive vesicles arrayed around the cell periphery. These may be involved in transporting adhesive or adhesive precursor material to the space between the cell wall and the cell membrane. A similar material seems to have accumulated in the region. C. Confocal laser scanning microscopy (CLSM) of conidia showing regions of staining by Con A. Some of the conidial cells show blobs of stained material on their surface. D. Close up of some conidia from C. E \& F.

Scanning electron micrographs of conidia attached to dipped coverslip. E. Overview of one conidium and its adhesive material. F. Tilted, higher magnification of conidium seen in Figure 4 E. Notice the globular protrusions on the conidium surface, and the heavy layer of adhesive material on its lower surface. All photographs made under Nomarski differential interference contrast optics. All bars $=10 \mu \mathrm{m}$

\section{Discussion}

The research of the effect of temperature on conidial formation at $18{ }^{\circ} \mathrm{C}$ and $28{ }^{\circ} \mathrm{C}$ of the fungus $\mathrm{A}$. helianthi showed there are huge differences in gross appearance of these conidia as well as ultrastructural properties. Conidia grown at $18{ }^{\circ} \mathrm{C}$ were more aggressive, vigorous and virulent as shown by mortality of cocklebur plants. The conidia produced at $28{ }^{\circ} \mathrm{C}$ did not cause mortality or other symptoms on cocklebur and other hosts. These physical findings correlated with ultrastructural characteristics under both light and electron microscopy. These results are in agreement with our previous results studying the influence of temperature on the virulence of $A$. helianthi on several plant hosts including cocklebur (Abbas \& Egley, 1996; Abbas et al., 1995; Abbas et al., 1996).

Using the CLSM, the adhesive material was distributed in different ways in various conidia. Some conidia had globules of material and other had a more even distribution. When the TEM was used, the $18{ }^{\circ} \mathrm{C}$ conidia had many ribosomes and much endoplasmic reticulum that indicated active synthesis cytoplasm was occurring. The adhesive vesicles were concentrated on or near cell walls. There was an osmophilic material between the cell wall and the cell membrane that presumably is the adhesive substance itself. It is possible when the correct stimulus is received, the material will pass through the cell wall and glue the conidium to the host plant. These 
sticky materials have been referred to as adhesive vesicles (Mims et al., 1995a; Nicholson \& Epstein, 1991). It has been reported that these adhesive materials appear to disappear with exposure to heat in that they are greatlyreduced in number after $24 \mathrm{hrs}$ and are extremely rare after that (Hyde et al., 1991; Oliveira et al., 2013). When Deising et al., 1992 discovered the adhesion in Uromyces, they provided evidence that serine esterases are essential to the adherence of the pad to the leaf surface. In addition to two nonspecific serine esterases, a cutinase was found to be localized on the spore surface. These enzymes were released rapidly from the spore surface upon contact with an aqueous environment. Restoration of the enzymes to the adhesive pads of autoclaved spores made the dead spores adhesive again (Deising et al., 1992). Also, when Silva et al., 2014 addressed the role of the adhesive materials in the pathogenicity of A. infectoria, they found about 20 identified proteins, polysaccharides, enzymes involved in the synthesis of pigment, adhesion of material to the host cell and transport of vesicles and other cellular substances inside the cell. They concluded that extracellular vesicles might have a major role in the virulence of A. infectoria (Silva et al., 2014). It has been reported extensively in (Nicholson \& Epstein, 1991; Oliveira et al., 2013) that multiple fungi have been determined to produce adhesive material that is important in the pathogenicity of the fungi, allowing fungal organisms to attach themselves to the host in a way that they are not easily dislodged. This study showed that these adhesive vesicles are important in the pathogenicity of $A$. helianthi to common cocklebur and other hosts. We have shown that conidia of $A$. helianthi produced at $18{ }^{\circ} \mathrm{C}$ are more vigorous than those produced at $28{ }^{\circ} \mathrm{C}$. The electron microscopy demonstrated that adhesive vesicles are more numerous and produce more mucilage at $18{ }^{\circ} \mathrm{C}$ that $28^{\circ} \mathrm{C}$. This is consistent with the adhesive vesicles being the delivery system of $A$. helianthi to infect common cocklebur and other hosts. More recently, Oliveira et al., 2013 described extracellular vesicles and their contents. These extracellular vesicles were originally intracellular vesicles produced by endoplasmic reticulum. Vesicles were found to contain virulence factors for fungi. This correlates with the adhesive vesicles produced by $A$. helianthi that seem to enable the conidia to attach to the host plant.

\section{Conclusion}

Overall, conidia produced at $18{ }^{\circ} \mathrm{C}$ are the most virulent, as confirmed by microscopic studies. Production temperature is an important factor to consider for biocontrol of common cocklebur by $A$. helianthi. Adhesive vesicles are present in conidia produced at $18{ }^{\circ} \mathrm{C}$ and not in conidia produced at $28{ }^{\circ} \mathrm{C}$. This observation might indicate an important role for adhesive vesicles in the virulence of $A$. helianthi conidia. This substance may play an important role in the virulence of $A$. helianthi to common cocklebur and survival of this pathogen. Further research would be helpful to understand the identity of the adhesive substance and its synthesis in A. helianthi.

\section{Acknowledgements}

We thank Ms. Bobbie J. Johnson and Jeremy K. Kotowicz for their valuable assistance in conducting this research. We are grateful to Dr. Efrem Bechere and Ellen Keene for their technical assistance.

\section{References}

Abbas, H. K., \& Barrentine, W. L. (1995). Alternaria helianthi and imazaquin susceptible and resistant cocklebur (Xanthium strumarium) biotypes. Weed Science, 43, 425-428.

Abbas, H. K., \& Egley, G. H. (1996). Influence of unrefined corn oil and surface-active agents on the germination and infectivity of Alternaria helianthi. Biocontrol Science and Technology, 6, 531-538. http://dx.doi.org/10.1080/09583159631163

Abbas, H. K., Egley, G. H., \& Paul, R. N. (1995). Effect of conidia production temperature on germination and infectivity of Alternaria helianthi. Phytopathology, 85(6), 677-682. http://dx.doi.org/10.1094/Phyto-85-677

Abbas, H. K., Johnson, B. J., \& Egley, G. H. (1996). Biological control of common cocklebur by Alternaria helianthi. Second International Weed Control Congress (pp. 1229-1234). Copenhagen, Denmark.

Abbas, H. K., Johnson, B. J., Pantone, D. J., \& Hines, R. (2004). Biological control and use of adjuvants against multiple seeded cocklebur (Xanthium strumarium) in comparison with several other cocklebur types. Biocontrol Science and Technology, 14(8), 855-860. http://dx.doi.org/10.1080/09583150410001720653

Abbas, H. K., Pantone, D. J., \& Paul, R. N. (1999). Characteristics of multiple seeded cocklebur (MSC): A biotype of common cocklebur (Xanthium strumarium L.). Weed Technolog, 13, 257-263.

Abbas, H. K., Paul, R.N., Boyette, C. D., Duke, S. O., \& Vesonder, R. F. (1992). Physiological and ultrastructural effect of fumonisin on jimsonweed leaves. Canadian Journal of Botany, 70(9), 1824-1833. http://dx.doi.org/10.1139/b92-226

Bloomberg, J. R., Kirkpatrik, B. L., \& Wax, L. M. (1982). Competition of common cocklebur (Xanthium 
pennsylvanicum) with soybean (Glycine max). Weed Science, 30, 507-513.

Buchanan, G. A., \& Burns, E. R. (1971). Weed competition in cotton: II. Cocklebur and redroot pigweed. Weed Science (19), 580-582.

Cleary, M. R., Daniel, G., \& Stenlid, J. (2013). Light and scanning electron microscopy studies of the early infection stages of Hymenoscyphus pseudoalbidus on Fraxinus excelsior. Plant pathology, 62, 1294-1301. http://dx.doi.org/10.1111/ppa.12048

Dan, S. U., Ru-jun, Z., Xue-rui, Y., Shu-yi, Y., \& Jun-Fan, F. (2012). Infection and establishment of Ascochyta anemones in leaves of windflower. African Journal of Microbiology Research, 6(23), 4983-4988.

Deising, H., Nicholson, R. L., Haug, M., Howard, R. J., \& Mendgen, K. (1992). Adhesion pad formation and the involvement of cutinase and esterases in the attachment of uredospores to the host cuticle. Plant Cell, 4, 1101-1111. http://dx.doi.org/10.1105/tpc.4.9.1101

Garcia, A., Rhoden, S. A., Filho, C. J., Nakamura, C. V., \& Pamphile, J. A. (2012). Diversity of foliar endophytic fungi from the medicinal plant Sapindus saponaria L. and their localization by scanning electron microscopy. Biol. Res, 45, 139-148. http://dx.doi.org/10.4067/S0716-97602012000200006

Holm, L. G., Plucknettl, D. L., Pancho, J. V., \& Herberger, J. P. (1977). The world's worst weeds: distribution and biology. An East-West Center Book from the East-West Food Institute, University Press of Hawaii, Honolulu.

Hyde, G. J., Lancelle, S., Hepler, P. K., \& Hardham, A. R. (1991). Sporangial structure in Phytophthora is disrupted after high pressure freezing. Protoplasma, 165, 203-208. http://dx.doi.org/10.1007/BF01322290

Kunoh, H., Yamaoka, N., Yoshioka, H., \& Nicholson, R. L. (1988). Preparation of the infection court by Erysiphe graminis. I. Contact-mediated changes in morphology of the conidium surface. Exp. Mycol, 12, 325-335. http://dx.doi.org/10.1016/0147-5975(88)90024-2

Mecure, E.W., Leite, B., \& Nicholson, R. L. (1994). Adhesion of ungerminated conidia of Colletotrichum graminicola to artificial hydrophobic surfaces. Physiological and Molecular Plant Pathology, 45, 421- 440. http://dx.doi.org/10.1016/S0885-5765(05)80040-2

Mecure, E.W., Kunoh, H., \& Nicholson, R. L. (1995). Visualizaiton of materials released from adhered, ungerminated conidia of Colletotrichum graminicola. Physiological and Molecular Plant Pathology, 46, 121-135. http://dx.doi.org/10.1006/pmpp.1995.1010

Mims, C.W., Liljebjelke, K. A., \& Richardson, E. A. (1995a). Surface morophology, wall structure, and initial adhesion of conidia of the powdery mildew fungus Uncinuliella austrialian. Phytopathology, 85(3), 352-358. http://dx.doi.org/10.1094/Phyto-85-352

Mims, C. W., Richardson, E. A., Clay, R. P., \& Nicholson, R. L. (1995b). Ultrastructure of conidia and the conidium aging process in the plant pathogenic fungus Colletotrichum Graminicola. International Journal of Plant Science, 156(1), 9-18. http://dx.doi.org/10.1086/297223

Mims, C. W., Rogers, M. A., \& Van Dyke, C. G. (1997). Ultrastructure of conidia and the conidum germination in the plant pathogenic fungus Alternaria cassia. Canadian Journal of Botany, 75, 252-260. http://dx.doi.org/10.1139/b97-027

Morris, J. B, Yang, S. M., \& Wilson, L. (1983). Reaction of Helianthus species to Alternaria helianthi. Plant Disease, 67(5), 539-540. http://dx.doi.org/10.1094/PD-67-539

Nasu, H., \& Kunoh, H. (1987). Scanning electron microscopy of flyspec of apple, pear, Japanese persimmon, plum, Chinese quince, and pawpaw. Plant Disease, 71, 361-364. http://dx.doi.org/10.1094/PD-71-0361

Nicholson, R. L., \& Epstein, L. (1991). Adhesion of fungi to the plant surface prerequisite for pathogenesis. In G. T. Cole \& H. C. Horn (Eds.). The Fungal Spore and Disease Initiation in Plants and Animals (Chapter 1, pp. 1-23). New York: Plenum Press. http://dx.doi.org/10.1007/978-1-4899-2635-7_1

Oliveira, D. L., Rizzo, J., Joffe, L. S., Godinho, R. M. C., \& Rodrigues, M. L. (2013). Where do they come from and where do they go: Candidates for regulating extracellular vesicle formation in fungi. International Journal of Molecular Sciences, 14, 9581-9603. http://dx.doi.org/10.3390/ijms14059581

Quimby, P. C., Jr. (1989). Response of common cocklebur (Xanthium strumarium L.) to Alternaria helianthi. Weed Technology, 3, 177-181.

Sanyal, D., Bhowmik, P. C., \& Abbas, H. K. (2008). Effect of surfactants on bioherbicial activity of Alternaria 
helianthi on multiple-seeded cocklebur. Plant Pathology Journal, 7(1), 104-108. http://dx.doi.org/10.3923/ppj.2008.104.108

Silva, B. M. A., Prados-Rosales, R., Espadas-Moreno, J., Wolf, J. M., Luque-Garcia, J. L., Goncalves, T., \& Casadevall, A. (2014). Characterization of Alternaria infectoria extracellular vesicles. Medical Mycology, 52, 202-210. http://dx.doi.org/10.1093/mmy/myt003

Soltani, N., Shropshire, C., \& Sikkema, P. H. (2010). Control of common cocklebur (Xanthium strumarium L.) in corn. Canadian Journal of Plant Science (90), 933-938. http://dx.doi.org/10.4141/cjps10065

Weaver, S. E., \& Lechowicz, M. J. (1983). The biology of Canadian weeds. 56. Xanthium strumarium L. Canadian Journal of Plant Science, 63, 211-225. http://dx.doi.org/10.4141/cjps83-021

\section{Copyrights}

Copyright for this article is retained by the author(s), with first publication rights granted to the journal.

This is an open-access article distributed under the terms and conditions of the Creative Commons Attribution license (http://creativecommons.org/licenses/by/3.0/). 